\title{
XIV. Description of an improved German key for extracting teeth
}

\section{Mr. Charles Brown}

To cite this article: Mr. Charles Brown (1798) XIV. Description of an improved German key for extracting teeth , Philosophical Magazine Series 1, 2:5, 73-74, DOI: $10.1080 / 14786449808676882$

To link to this article: http://dx.doi.org/10.1080/14786449808676882

曲 Published online: 18 May 2009.

Submit your article to this journal $\sqsubset \pi$

Џ Article views: 2

Q View related articles $\sqsubset$ 
From the defcription that has been given of the procefs, no perfon can be at any lofs in reforting to the fame kind of fumigation. It is only neceffary to obferve, for the fake of thofe who may not be verfant in chemical purfuits, that the ingredients ought to be pure, and that metal veffels or rods muit not be employed. Any kind of metal getting among the ingredients would caufe the vapour to be very noxious, inftead of falutary. The fumes that rife fhould be white; if they are of a red colour, there is reafon to fulpect the purity of the ingredients.

The importance of this difcovery need not be infifted on: it is equally applicable to every fpecies of putrid contagion, even to the plague itfelf. It fhould therefore be ufed in all hofpitals and parifh workhoufes; and fhould be conftantly reforted to by the proprietors of all large works, on the firft appearance of infectious difeafe among the people employed in them :-indeed, it fhould be employed even as a preventive in all fituations, where a number of people, from the nature of their bufinefs, are obliged to be crowded together, or where, from local circumftances, there are reafons for fufpecting that the purity of the air is injured by noxious exhalations or other caufes. If there be any circumftances in which its utility might be called in queftion, it can only be in cafes of inflammatory difeafes; for, in fuch, fuperoxygenation has been found hurtful.

XIV. Defcription of an improved German Key for extracting Teetb. By Mr. Charles Brown, Surgeon. Communicated by the Inventor.

IHE obfervations with which you accompanied the announcement of my improvement in your laft number, renders any introduction to the defcription of the inftrument unneceffary.

The handle A (Plate II.) is made of ivory, very largs and heavy, with the view of giving greater purchafe to the operator.

$B$ is 


$$
55
$$


$B$ is a circular milled projection on one end of the lever $B K$, and ferves as a thumb-piece to be preffed into the thank againft a fpring placed below the fame end of the lever; by which means the end $K$ is raifed fo as to unlock the claw when it is wifhed to be turned to another fide of the inftrument.

H thows a fection of this part of the inftument, where $I$ reprefents the fpring that is acted upon by preffing down the thumb-piece $B$, fo as to raife the end $K$ of the lever, to difcharge it from the notch in the heel of the claw when the latter is wifhed to be moved to a new pofition.

$\mathrm{C}$, the claw, is made to come off that at its lower extremity, and roughed on the infide, which, with the fhoulder $E$, forms a bed to receive the tooth.

$D$, the bolfter, is made concave, to anfwer to the convexity of the teeth.

$G$, the heel of the claw, has four, fix, or a greater number of notches round it, fitted to receive the end $K$ of the lever.

The improvements introduced into this inftument are fuch as I hope will be found to remedy the defeets complained of in all former ones; and the facility with which a tooth can be drawn by its means, will, I am fure, render its adoption in practice univerfal, as foon as it fhall be generally known.

XV. On the Ufe of the new Metal called Cbrome, the Oxyd of Cbrome, and the Cbromie Acid. By Cit. VA UQUELIN. From the Journal des Mines, No. XXXIV.

$T_{H}$ action of fire, and the fmallnefs of the maffes in which it has hitherto been naturally found, do not leave us any hopes that this metal can ever be of great utility in the arts. This affertion, however, may be going rather a little too far; for a new fubftance, the properties of which do not at firft feem 